\title{
Perceived Stress and its Triggers among Pharmacy University Students in Comparison to Student of Other Faculties: A Cross Sectional Study
}

\author{
Syed Mohammed Basheeruddin Asdaq ${ }^{1, *}$, Mohammed Kanan Alshammari ${ }^{2}$, Asma Basheer Alsirhani ${ }^{3}$, \\ Jawaher Basheer Alsirhani ${ }^{2}$, Alhanoof Munawer Alshammari ${ }^{4}$, Mohd Imran ${ }^{5}$, Abdulhakeem S. \\ Alamri' $^{6,7}$, Majid Alhomrani ${ }^{6,7}$, Walaa F. Alsanie ${ }^{6,7}$, Nagaraja Sreeharsha ${ }^{8,9}$ \\ ${ }^{1}$ Department of Pharmacy Practice, College of Pharmacy, Al Maarefa University, Dariyah, Riyadh, SAUDI ARABIA, \\ ${ }^{2}$ Department of Pharmaceutical Care, Rafha Central Hospital, North Zone, Rafha, SAUDI ARABIA. \\ ${ }^{3}$ Aldawaa Pharmacies, Hail, SAUDI ARABIA. \\ ${ }^{4}$ AI-Dawaa Medical Services Company (DMSCO), North Zone, Hail, SAUDI ARABIA \\ ${ }^{5}$ Department of Pharmaceutical Chemistry, Faculty of Pharmacy, Northern Border University, Rafha, SAUDI ARABIA. \\ ${ }^{6}$ Department of Clinical Laboratories Sciences, College of Applied Medical Sciences, Taif University, Taif, SAUDI ARABIA. \\ ${ }^{7}$ Centre of Biomedical Sciences Research (CBSR), Deanship of Scientific Research, Taif University, Taif, SAUDI ARABIA. \\ ${ }^{8}$ Department of Pharmaceutical Sciences, College of Clinical Pharmacy, King Faisal University, Al-Ahsa, SAUDI ARABIA. \\ ${ }^{9}$ Department of Pharmaceutics, Vidya Siri College of Pharmacy, Off Sarjapura Road, Bangalore, Karnataka, INDIA.
}

\begin{abstract}
Background and Objectives: The role of stress in causing mental and physical damage is well known. The deleterious effect of stress is more dominant in young university students as they encounter repeated examinations amidst high expectation from the society. This study is an attempt to uncover the impact of stress on the university students and compare the level of stress among students of different health science programs. Materials and Methods: This cross-sectional comparative study was carried out using standardized and validated questionnaire by self-administration method. The questionnaire was distributed manually to the students at college of medicine, pharmacy and applied sciences at one of the accredited private universities of Saudi Arabia. The questionnaire contained demographic information, a perceived stress scale, stressors and stress relievers. The data was examined using analysis of variance and post-hoc testing. $P \leq 0.05$ was chosen as the statistical significance level. Results: Most of the respondents in this survey $(73 \%)$ were between the ages of 18 and 25 , with a balanced distribution of participants from medical $(34 \%)$ pharmacy $(33 \%)$ and applied sciences $(33 \%)$ colleges. According to our statistics, the stress level among college of medical students was significantly greater than that of students in the college of applied sciences. Furthermore, on the perceived stress scale, students from both the college of pharmacy and the college of medicine reported higher levels of stress. Academic difficulties were a major source of stress for most students. Conclusion: Students in all three fields of study reported feeling anxious, although it shows that applied science college students are less stressed than medical and pharmacy students. The most major stressors are academic variables, prompting the development of specific and targeted treatments to significantly reduce the stress burden on students. Students' needs should be addressed through teaching methods and academic atmosphere. Finally, students can lower their stress levels by acquiring effective study habits and time management skills.
\end{abstract}

Key words: Stress, University students, Stress relievers, Medicine, Pharmacy, Applied Science, Stress management.
Submission Date: 15-11-2021; Revision Date: 10-12-2021; Accepted Date: 02-01-2022.

DOI: 10.5530/ijper.56.1s.48 Correspondence: Dr. Syed Mohammed Basheeruddin Asdaq Professor, Department of Pharmacy Practice, College of Pharmacy, Al Maarefa University, Dariyah-13713, Riyadh, SAUDI ARABIA. E-mail: sasdaq@gmail.com

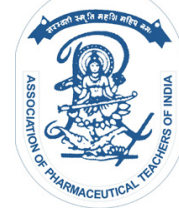

www.ijper.org 


\section{INTRODUCTION}

Stress is defined as any disruption of stability in which the individual is unable to meet the demands placed on him1. It may result in poor decision-making and an increase in mental illness including suicidal ideation. ${ }^{1} \mathrm{It}$ has the potential to lower students' self-esteem and have an impact on academic performance as well as individual and career development. ${ }^{2-5}$ Furthermore, both males and females had the same level of stress, ${ }^{6}$ with rural residents experiencing much fewer stressors than urban residents, indicating that strong family relationship in rural regions. ${ }^{7}$ Additionally, the impact of race and ethnicity ${ }^{8}$ on varying degrees of stress has been reported, with a higher incidence amongst professional women than professional men. ${ }^{9,10}$

The effects of stress on several aspects of society are extensively established. Students, who are at the forefront of stresses such as shifting learning resources, frequent transitional periods, high societal expectations, and the availability of instant academic measurements, are routinely examined for stress generating and relieving elements. One Saudi Arabian research documented no perceived stress over time among first year university students, ${ }^{11}$ whereas girls in their secondary school studies were shown to have a higher prevalence of stress with depression and anxiety. ${ }^{12}$ Furthermore, multiple studies have concluded that there is a high frequency of stress among university students in various regions of the world, which has a negative impact on their academic performance. ${ }^{13-17}$ Exams $^{18}$ and increasing academic demands ${ }^{19}$ are two important factors that contribute to the development of stress in university students, with a high incidence of stress in both genders at the preclinical stage. ${ }^{20-23}$

It is an undeniable reality that stress is an essential component of any successful outcome. It is the ability to deal with stress that is thought to be the deciding factor between success and failure. Because university students are more likely to experience stress, it's important to understand its causes and develop techniques to alleviate it. Even though several studies have been conducted in Saudi Arabia and elsewhere to establish the prevalence of stress among medical students, ${ }^{15-19}$ there are few ways for dealing with it. Except one study done in Saudi Arabia, ${ }^{24}$ most studies on university health science students in the literature focus on the medical stream, minimal efforts have been made to understand the trend of stress levels among non-medico health university students. ${ }^{25-28}$ As a result, this research was performed to investigate the level of stress and its triggers among University students, as well as to compare the levels of stress experienced by students in the college of pharmacy, college medicine and college of applied sciences in one of the accredited private universities of Saudi Arabia.

\section{MATERIALS AND METHODS \\ Sampling}

The current research was based on a cross-sectional study of Al Maarefa University students in Riyadh, Saudi Arabia. During March to May 2021, the questionnaire was self-administered to the participants. The data was collected using a standardized questionnaire that had been pre-designed and tested. The survey was fully optional, and complete secrecy and confidentiality were always maintained. A consent form outlining the study's objective and requesting their participation was added to the beginning of the questionnaire.

\section{Study Design}

A cross-sectional comparative study design was used to conduct the current investigation. Since the time selected for the study had relatively less assessments so chances of additional stress are expected to be less, we opted for cross-section design. Also, the responses of the students at each college of the University were supposed to be compared with each other, we termed this study as comparative. To address research questions, the study used a questionnaire design. The questionnaire was developed following a thorough assessment of the literature and discussions with experts in the field. Following its validation, the questionnaire was put through pilot research with a small number of study participants. The questionnaire was fine-tuned and refined based on the results of the pre-test.

\section{Study tool}

The study tool was divided into five sections. The first section included the participants' demographic information as given in Table 1. The second section included questions about gauging students' stress using a standard perceived stress scale. This portion featured ten statements regarding the participants' moods and thoughts throughout the previous month. The mean is the average of the responses, which represents the overall answer of each college. Third section had items to determine the triggers/stressors that may be responsible for inciting, precipitating, or causing stress were also included in the study questionnaire in third section. Academic issues, health and lifestyle variables, and environmental factors were the three sub-categories 


\begin{tabular}{|c|c|c|}
\hline Characteristics & Frequency & Percentage \\
\hline \multicolumn{3}{|l|}{ Age } \\
\hline $18-22$ years & 353 & 73 \\
\hline 23-26 years & 98 & 20 \\
\hline $27-30$ years & 32 & 07 \\
\hline \multicolumn{3}{|l|}{ Gender } \\
\hline Female & 278 & 58 \\
\hline Male & 205 & 42 \\
\hline \multicolumn{3}{|l|}{ College } \\
\hline Medicine & 165 & 34 \\
\hline Pharmacy & 159 & 33 \\
\hline Applied Science & 159 & 33 \\
\hline \multicolumn{3}{|l|}{ Study level } \\
\hline $1-2$ & 62 & 13 \\
\hline $3-4$ & 79 & 16 \\
\hline $5-6$ & 120 & 25 \\
\hline $7-8$ & 128 & 27 \\
\hline More than or equal 9 & 94 & 19 \\
\hline \multicolumn{3}{|l|}{ GPA } \\
\hline Less than equal to 1 & 24 & 5 \\
\hline Between 1 to 2 & 72 & 15 \\
\hline Between 2 to 3 & 192 & 40 \\
\hline Between 3 to 4 & 195 & 40 \\
\hline \multicolumn{3}{|l|}{ Marital status } \\
\hline Married & 62 & 13 \\
\hline Unmarried & 421 & 87 \\
\hline \multicolumn{3}{|l|}{ Location } \\
\hline Urban & 373 & 77 \\
\hline Rural & 110 & 23 \\
\hline \multicolumn{3}{|l|}{ Nationality } \\
\hline Saudi & 363 & 75 \\
\hline Non-Saudi & 120 & 25 \\
\hline \multicolumn{3}{|l|}{ Educational status (father) } \\
\hline Illiterate & 10 & 02 \\
\hline Upto class 5 & 25 & 05 \\
\hline Upto class 12 & 86 & 18 \\
\hline University education & 362 & 75 \\
\hline \multicolumn{3}{|l|}{ Educational status (mother) } \\
\hline Illiterate & 35 & 07 \\
\hline Upto class 5 & 63 & 13 \\
\hline Upto class 12 & 156 & 32 \\
\hline University education & 229 & 47 \\
\hline \multicolumn{3}{|l|}{ Employment status (father) } \\
\hline Employed in health industry & 120 & 25 \\
\hline $\begin{array}{l}\text { Not employed or employed in } \\
\text { other industry }\end{array}$ & 363 & 75 \\
\hline \multicolumn{3}{|l|}{ Employment status (mother) } \\
\hline Employed & 240 & 50 \\
\hline Non-employed & 243 & 50 \\
\hline
\end{tabular}

of stresses. Fourth section had series of possible reliever for their perceived stress.

\section{Statistical analysis}

The data was entered and analysed using version 23 of the statistical program for social science (IBM SPSS Inc., Chicago, IL, USA). Frequencies and percentages were used to present the data. The data obtained were analysed using ANOVA and post ANOVA tests. The significance criteria were applied at a $P$-value of $\# 0.05$ for all purposes.

\section{RESULTS}

\section{Demographic features of the participants}

According to Table 1, 73\% of the students that participated in this survey were between the ages of 18 and 25 , with a slightly higher rate of female participation (58 Vs 42). Students from colleges of pharmacy and applied sciences each accounted for 33\% of the overall cohort, while students from colleges of medicine made for $34 \%$. Almost $70 \%$ of the students enrolled in our study had a study level of 5 or higher. Furthermore, 87 percent of the students enrolled were single, with $77 \%$ hailing from urban areas. Saudi nationals made up $34 \%$ of the participants, while non-Saudis of various nationalities made up $25 \%$. In addition, $75 \%$ of the students' fathers have a higher education (college or higher), whereas just $47 \%$ of the students' mothers have a higher education. Only $25 \%$ of the students have a father who is in the healthcare profession, whereas $50 \%$ of the students have non-working mothers.

\section{Perceived Stress}

Table 2 shows how participants in this study rated their experience on the perceived stress scale in the previous month. Students from the College of Applied Sciences gave significantly different ratings to students from the colleges of medicine and pharmacy on at least five of the ten items. When comparing College of Applied students to students from other colleges, the surveyors' confidence levels were much higher in item 4,5 , and 8 . Students at colleges of medical and pharmacy gave high ratings to items 7 and 9, which decide the participants' irritation and angriness in the previous month, while students in colleges of applied science gave low ratings to these two items.

\section{Stress trigger- Academic factors}

As indicated in Table 3, six of the eight items evaluated produced no significant variance among students from various colleges. Students in college of pharmacy have 


\section{Table 2: Perceived stress scale.}

\begin{tabular}{|c|c|c|c|c|c|}
\hline Number & Perception items & $\begin{array}{l}\text { College of } \\
\text { Medicine }\end{array}$ & $\begin{array}{l}\text { College of } \\
\text { Pharmacy }\end{array}$ & $\begin{array}{l}\text { College of } \\
\text { Applied } \\
\text { Science }\end{array}$ & $P$ value \\
\hline 1 & $\begin{array}{l}\text { In the last month, how often have you been upset } \\
\text { because of something that happened unexpectedly? }\end{array}$ & 2.65 & 2.45 & 2.2 & 0.07 \\
\hline 2 & $\begin{array}{l}\text { In the last month, how often have you felt that you were } \\
\text { unable to control the important things in your life? }\end{array}$ & 2.45 & 2.65 & 2.10 & 0.09 \\
\hline 3 & $\begin{array}{l}\text { In the last month, how often have you felt nervous and } \\
\text { "stressed"? }\end{array}$ & 2.95 & 2.86 & 2.32 & 0.26 \\
\hline 4 & $\begin{array}{l}\text { In the last month, how often have you felt confident about } \\
\text { your ability to handle your personal problems? }\end{array}$ & 2.1 & 2.2 & 3.2 & 0.02 \\
\hline 5 & $\begin{array}{c}\text { In the last month, how often have you felt that things were } \\
\text { going your way? }\end{array}$ & 1.92 & 1.8 & 3.4 & 0.01 \\
\hline 6 & $\begin{array}{l}\text { In the last month, how often have you found that you } \\
\text { could not cope with all the things that you had to do? }\end{array}$ & 2.6 & 2.7 & 2.10 & 0.43 \\
\hline 7 & $\begin{array}{l}\text { In the last month, how often have you been able to control } \\
\text { irritations in your life? }\end{array}$ & 3.2 & 3.1 & 2.1 & 0.021 \\
\hline 8 & $\begin{array}{l}\text { In the last month, how often have you felt that you were } \\
\text { on top of things? }\end{array}$ & 1.92 & 2.12 & 3.4 & 0.034 \\
\hline 9 & $\begin{array}{l}\text { In the last month, how often have you been angered } \\
\text { because of things that were outside of your control? }\end{array}$ & 2.8 & 3.0 & 2.1 & 0.031 \\
\hline 10 & $\begin{array}{l}\text { In the last month, how often have you felt difficulties were } \\
\text { piling up so high that you could not overcome them? }\end{array}$ & 2.2 & 2.3 & 1.92 & 0.06 \\
\hline
\end{tabular}

Notes: Likert response scale from o to $4(0=$ Never $\quad 1=$ Almost Never $2=$ Sometimes $3=$ Fairly Often $4=$ Very Often $)$

\begin{tabular}{|c|c|c|c|c|c|}
\hline \multirow{2}{*}{ Number } & Items & $\begin{array}{c}\text { College of } \\
\text { Medicine }\end{array}$ & $\begin{array}{c}\text { College of } \\
\text { Pharmacy }\end{array}$ & $\begin{array}{c}\text { College of } \\
\text { Applied } \\
\text { Science }\end{array}$ & $\begin{array}{c}\text { P value } \\
\text { Sable 3: }\end{array}$ \\
\hline 1 & Admission to this program was not my choice & 0.79 & 0.9 & 1.1 & 0.47 \\
\hline 2 & Self-satisfaction with study efforts & 1.4 & 1.3 & 1.4 & 0.91 \\
\hline 3 & The quality of the educational process at the college & 1.5 & 1.6 & 1.4 & 0.62 \\
\hline 4 & The presence of study-related problems & 1.8 & 1.8 & 2.1 & 0.29 \\
\hline 5 & An overloaded syllabus & 1.4 & 1.6 & 1.9 & 0.06 \\
\hline 6 & Satisfaction with the methods of teaching & 0.9 & 0.89 & 1.2 & 0.32 \\
\hline 7 & Frequent examinations & 1.2 & 2.1 & 1.2 & $\mathbf{0 . 0 1 2}$ \\
\hline 8 & Presentation in front of audience & 1.8 & 1.7 & 2.6 & $\mathbf{0 . 0 3 1}$ \\
\hline
\end{tabular}

Notes: Likert response scale from o to 3 ( $0=$ Not stressful, $1=$ Mild stress, $2=$ Moderate stress, $3=$ Extremely stressful)

\begin{tabular}{|c|c|c|c|c|c|}
\hline Number & Items & $\begin{array}{c}\text { College of } \\
\text { Medicine }\end{array}$ & $\begin{array}{c}\text { College of } \\
\text { Pharmacy }\end{array}$ & $\begin{array}{c}\text { College of } \\
\text { Applied Science }\end{array}$ & $\begin{array}{r}\boldsymbol{P} \text { value } \\
\hline 1\end{array}$ \\
\hline 2 & Mood breakdown & 1.12 & 1.4 & 1.3 & 0.74 \\
\hline 3 & Examination phobia & 1.32 & 1.43 & 1.8 & 0.86 \\
\hline 4 & Frustration and self-care & 1.8 & 1.7 & 1.8 & 0.34 \\
\hline 5 & Exercise & 1.8 & 1.7 & 1.8 & 0.93 \\
\hline 6 & Diet & 1.7 & 1.6 & 1.7 & 0.65 \\
\hline 7 & Financial problem & 1.9 & 1.8 & 1.7 & 0.54 \\
\hline 8 & Changes in sleep pattern & 2.0 & 2.2 & 2.2 & 0.43 \\
\hline 9 & Substance abuse & 1.3 & 1.2 & 1.6 & 0.32 \\
\hline
\end{tabular}


Table 5: Stressors- Environmental Factors.

\begin{tabular}{|c|c|c|c|c|c|}
\hline Number & Items & $\begin{array}{c}\text { College of } \\
\text { Medicine }\end{array}$ & $\begin{array}{c}\text { College of } \\
\text { Pharmacy }\end{array}$ & $\begin{array}{c}\text { College of } \\
\text { Applied Science }\end{array}$ & \begin{tabular}{l}
$\boldsymbol{P}$ value \\
\hline 1
\end{tabular} \\
\hline 2 & Relationship with other students & 1.24 & 1.42 & 1.65 & 0.074 \\
\hline 3 & Lack of recreational activities & 1.86 & 1.44 & 1.82 & 0.086 \\
\hline
\end{tabular}

\begin{tabular}{|c|c|c|c|c|c|}
\hline Number & Items & $\begin{array}{l}\text { College of } \\
\text { Medicine }\end{array}$ & $\begin{array}{l}\text { College of } \\
\text { Pharmacy }\end{array}$ & $\begin{array}{l}\text { College of Applied } \\
\text { Science }\end{array}$ & $P$ value \\
\hline 1 & Coffee and Tea & 48 & 52 & 48 & 0.14 \\
\hline 2 & Smoking & 20 & 24 & 31 & 0.26 \\
\hline 3 & Sleeping & 60 & 64 & 56 & 0.14 \\
\hline 4 & T.V watching & 25 & 30 & 28 & 0.23 \\
\hline 5 & Playing sport & 28 & 30 & 31 & 0.25 \\
\hline 6 & Talking with others & 38 & 32 & 36 & 0.34 \\
\hline 7 & Listen to music & 40 & 38 & 36 & 0.33 \\
\hline 8 & Taking bath & 32 & 31 & 34 & 0.22 \\
\hline 9 & Reading and listening Quran & 40 & 43 & 47 & 0.43 \\
\hline 10 & Shopping & 30 & 38 & 56 & 0.04 \\
\hline 11 & Reading book & 26 & 27 & 30 & 0.43 \\
\hline 12 & Visiting family and friends & 34 & 36 & 38 & 0.33 \\
\hline 13 & Others & 21 & 23 & 25 & 0.21 \\
\hline
\end{tabular}

identified frequent examination as a source of stress, whereas students in applied science colleges have given presentation a substantially higher ranking as a main source of stress.

\section{Stress trigger- Health and lifestyle factors}

Table 4 depicts the identification of health and lifestyle factors as stressors. For all students assessed in this study, regardless of their affiliated colleges, examination fear, and frustration are triggers on a stress scale. Mild stress is considered by all students in all collages with little variations in exercise, food, financial problems, substance addiction, and current minor or major illness. However, none of the comparison between different colleges were significantly varied from each other.

\section{Stress trigger- Environmental Factors}

The three items of the environmental system that can influence the induction of stress are shown in Table 5. Students from all three colleges regarded relationships with classmates, a lack of recreational activities, and high academic expectations as moderate stressors. There was no significant variance between them.

\section{Stress relievers}

Table 6 shows a variety of stress relievers that may be employed by university students. When compared to students from colleges of medicine and pharmacy, a significantly higher percentage of students from colleges of applied sciences would choose to go shopping to relieve stress. Coffee/tea is preferred by many students from all three universities as a stress reliever. Approximately $40 \%$ of students across all colleges would prefer to read the sacred book Quran when they are stressed.

\section{DISCUSSION}

This research was carried out to establish the degree of stress, common stressors, and current stress reliever practices students at the university adopt. The information gathered was evaluated and compared among Al Maarefa's faculties, including the colleges of medicine, pharmacy, and applied sciences. When comparing students at colleges of medical and pharmacy to students at colleges of applied sciences, the study found that students in colleges of medicine and pharmacy have a higher prevalence of stress.

The majority of the present study's respondents $(73 \%)$ were between the ages of 18 and 22, and participation from each college was nearly identical. Most of the students who participated in this study were at their middle or higher level of studies in their respective 
programs. The students at college of medicine were studying MBBS, while the college of pharmacy students were involved in pursuing Pharm.D. program. The college of applied sciences students were enrolled for different programs such as nursing, emergency medical services, anesthesia technology, and respiratory care. A high percentage of students who participated were with good GPA (3 to 4) so we expect a good quality of their feedback in the study. The timing of the study was suitably matched with the semester plan and kept at the time of the semester where students have relatively less examination or additional stress. Despite taking all precautions, we found significantly high level of stress among medical and pharmacy college students when compared to students of applied sciences programs. These observations are consistent with earlier publications carried out on elucidating the stress among university medical students. ${ }^{29}$ The students of AlMaarefa were found in our study were not able to cope up with the regular daily activities in their life probably due to the high academic demands of their programs. The imbalance between the demand of the program and coping up strategies of the students has been reported in earlier studies as well. ${ }^{30}$

Academic stresses produced the most stress across academic, environmental, health, and lifestyle stressors. This observation is consistent with earlier research. ${ }^{31,32}$ This finding is supported by other investigations in the literature. ${ }^{33}$ Students from AlMaarefa's various colleges describe these stresses as "moderate stress," with a slightly higher level in the students at pharmacy college. Examination phobia is well documented trigger identified in previous studies as well. ${ }^{34,35}$ This could be due to a lack of free time and high pressure, both of which impede students' capacity to adopt a healthy lifestyle. The contribution of major and minor illness is found to be the stress inducer in this study, ${ }^{36,37}$ however, one study contradicts these findings. ${ }^{32}$ Finally, among external stressors, high expectations for academic accomplishment were the most common stressor among students from AlMaarefa's colleges. Lack of leisure activities was identified as a mild stressor by several AlMaarefa colleges in our study. Several other investigations have shown comparable results. ${ }^{34,35}$

In this study, current stress reliever habits revealed coffee/tea and sleeping. Smoking and reading books were employed to a lesser extent as stress relievers than the other activities indicated in Table 6. Students in a Nigerian medical school used smoking as a stress reliever the least, according to Afiong Oboko Oku, $2015,{ }^{38}$ which is consistent with our findings. In contrast, the same study discovered that as a coping strategy, they had a higher risk of social disengagement from friends and family. Unlike our study, where talking and visiting relatives and friends to ease stress was more common.

\section{Limitation and recommendation for future studies}

Our study had at least two limitations, even though it achieved its objectives. First, the findings are based on a recall from the participants that may lead to recall bias. There is also chance of confounding factors that are not included or considered in this study.

\section{CONCLUSION}

Although applied science college students are less worried than medical and pharmacy students, students in all three fields of study reported feeling anxious. Academic variables are the most common stressors, driving the creation of particular and focused treatments that considerably reduce student stress. The demands of students should be served through teaching methods and an academic environment. Finally, effective study habits and time management abilities can help students reduce their stress levels.

\section{Funding}

The author Majid Alhomrani was supported by Taif University with number (TURSP 2020/257), Taif University, Taif, Saudi Arabia.

\section{ACKNOWLEDGEMENT}

Syed Mohammed Basheeruddin Asdaq, would like to thank AlMaarefa University, Riyadh, Saudi Arabia for extending support (TUMA-2021-1) to do this research.

\section{CONFLICT OF INTEREST}

The authors declare that there is no conflict of interest.

\section{REFERENCES}

1. Waghachavare Vivek B, Dhumale Girish B, Kadam Yugantara R, Gore Alka D. A Study of Stress among Students of Professional Colleges from an urban area in India. Sultan Qaboos Univ Med J. 2013;13(3):429-36. PMID 23984029.

2. Yusoff Muhamad Saiful Bahri, Abdul Rahim Ahmad Fuad, Yaacob Mohd Jamil. Prevalence and sources of stress among Universiti Sains Malaysia medical students. Malays J Med Sci. 2010;17(1):30-7. PMID 22135523.

3. Ben Loubir Dalal, Serhier Zeineb, Diouny Samir, Battas Omar, Agoub Mohamed, Bennani Othmani Mohammed. Prevalence of stress in Casablanca medical students: a cross-sectional study. Pan Afr Med J. 2014;19:149. doi: 10.11604/pamj.2014.19.149.4010, PMID 25767668.

4. Nieto M, Romero D, Ros L, Zabala C, Martínez M, Ricarte JJ, Serrano JP, Latorre JM. Differences in coping strategies between young and older adults: 
The role of executive functions. The International Journal of Aging and Human Development. 2020 Jan;90(1):28-49.

5. Kuhlmann Sophie Merle, Bürger Arne, Esser Günter, Hammerle Florian. A mindfulness-based stress prevention training for medical students (MediMind): study protocol for a randomized controlled trial. Trials. 2015;16(1):40. doi: 10.1186/s13063-014-0533-9, PMID 25887430.

6. Glise K, Ahlborg G, Jonsdottir IH. Prevalence and course of somatic symptoms in patients with stress-related exhaustion: Does sex or age matter. BMC Psychiatry. 2014;14(1):118. doi: 10.1186/1471-244X-14-118.

7. Webb Stephen D, Collette John. Rural-urban differences in the use of stress-alleviative drugs. AJS. 1977;83(3):700-7. doi: 10.1086/226600, PMID 931045.

8. Alegría Margarita, Fortuna Lisa R, Lin Julia Y, Norris Fran H, Gao Shan, Takeuchi David T, et al. Prevalence, risk, and correlates of posttraumatic stress disorder across ethnic and racial minority groups in the United States. Med Care. 2013;51(12):1114-23. doi: 10.1097/MLR.0000000000000007, PMID 24226308.

9. Wiegner Lilian, Hange Dominique, Björkelund Cecilia, Ahlborg Gunnar Prevalence of perceived stress and associations to symptoms of exhaustion, depression and anxiety in a working age population seeking primary care--an observational study. BMC Fam Pract. 2015;16(1):38. doi: 10.1186/s12875015-0252-7, PMID 25880219.

10. Zaletel-Kragelj Lijana, Pahor Majda, Bilban Marjan. Identification of population groups at very high risk for frequent perception of stress in Slovenia. Croat Med J. 2005;46(1):137-45. PMID 15726688.

11. Al-Daghri Nasser M, Al-Othman Abdulaziz, Albanyan Abdulmajeed, Al-Attas Omar S, Alokail Majed S, Sabico Shaun, et al. Perceived stress scores among Saudi students entering universities: A prospective study during the first year of university life. Int J Environ Res Public Health. 2014;11(4):3972-81. doi: 10.3390/ijerph110403972, PMID 24727357.

12. Al-Gelban Khalid S, Al-Amri Hasan S, Mostafa Ossama A. Prevalence of depression, anxiety and stress as measured by the depression, anxiety, and stress scale (DASS-42) among secondary school girls in Abha, Saudi Arabia. Sultan Qaboos Univ Med J. 2009;9(2):140-7. PMID 21509290.

13. Phang Cheng Kar, et al. Prevalence of psychological stress among undergraduate students attending a health programme in a Malaysian University. Pertanika J Sci Technol. 2015;23(1):29-35.

14. Kim NC, Kim SH, Lhm HK, Kim JH, Jung HS, Park JC, Kim YS. Comparison of stress and life satisfaction between non-medical and medical college students. Korean Journal of Psychosomatic Medicine. 2015;23(1):47-56.

15. Ludwig Allison B, Burton William, Weingarten Jacqueline, Milan Felise, Myers Daniel C, Kligler Benjamin. Depression and stress amongst undergraduate medical students. BMC Med Educ. 2015;15(1):141. doi: 10.1186/s12909015-0425-z, PMID 26311538.

16. Sohail N. Stress and academic performance among medical students. J Coll Physicians Surg Pak. 2013 Jan 1;23(1):67-71.

17. Asad M, Alenezi A, Alsalowly MN, Basheeruddin SM, Alrashed IN, Almutairi MF, Aldhawyan NN, Alharbi MA, Alsallami OO, Sreeharsha N. Self-reported Anxiety and Coping: A Cross-Sectional Study among Saudi Nursing Students during COVID-19 Pandemic using Gad-7 and Briefcope. Indian Journal of Pharmaceutical Education and Research. 2021:S637-45.

18. Kumari R, Sharma M. Evaluated Stress and Anxiety in College Students before and After Midterm Exam. Medico Legal Update. 2021 Mar 12;21(2):1024-9.

19. Othman CheNoriah, Farooqui M, Yusoff MSB, Adawiyah R. Nature of stress among health science students in a Malaysian University. Procedia Soc Behav Sci. 2013;105:249-57. doi: 10.1016/j.sbspro.2013.11.026.

20. Al Sunni, Ahmed, Latif Rabia. Perceived stress among medical students in preclinical years: A Saudi Arabian perspective; 2014.

21. Sani M, et al. Prevalence of stress among medical students in Jizan University, Kingdom of Saudi Arabia. Gulf Med J. 2012;1(1):19-25.
22. Abdel Rahman AG, Al Hashim BN, Al Hiji NK, Al-Abbad Z. Stress among medical Saudi students at college of medicine, King Faisal University. J Prev Med Hyg. 2013;54(4):195-9. PMID 24779279.

23. Sultan Saud A, et al. Prevalence of depression among medical students at. Madinah, Saudi Arabia: Taibah University.

24. Asdaq B. Prevalence of stress and its associated factors among students of Al-Maarefa Colleges of Riyadh, Saudi Arabia: A comparative cross-sectional study. Asian Journal of Pharmaceutics (AJP): Free full text articles from. Asian J Pharm. 2018;12(02).

25. Seedhom AE, Kamel EG, Mohammed ES, Raouf NR. Predictors of perceived stress among medical and nonmedical college students, Minia, Egypt. International journal of preventive medicine. 2019;10.

26. Al-Dabal Badria K, Koura Manal R, Rasheed Parveen, Al-Sowielem Latifa, Makki Suhair M. A comparative study of perceived stress among female medical and non-medical university students in Dammam, Saudi Arabia. Sultan Qaboos Univ Med J. 2010;10(2):231-40. PMID 21509235.

27. Kulsoom Bibi, Afsar Nasir Ali. Stress, anxiety, and depression among medical students in a multiethnic setting. Neuropsychiatr Dis Treat. 2015;11:1713-22. doi: 10.2147/NDT.S83577, PMID 26213470.

28. Tam CC, Benotsch EG, Weinstein TL. Resilience and psychiatric symptoms as mediators between perceived stress and non-medical use of prescription drugs among college students. The American journal of drug and alcohol abuse. 2020 Jan 2;46(1):120-30.

29. Al-Dabal Badria K, Koura Manal R, Rasheed Parveen, Al-Sowielem Latifa, Makki Suhair M. A comparative study of perceived stress among female medical and non-medical university students in Dammam, Saudi Arabia. Sultan Qaboos Univ Med J. Aug 2010;10(2):231-40. PMID 21509235.

30. Chowdhury Ranadip, Mukherjee Abhijit, Mitra Kaushik, Naskar Somnath, Karmakar Prasanta Ray, et al. Perceived psychological stress among undergraduate medical students: Role of academic factors. Indian J Public Health. 2017;61(1):55-7. doi: 10.4103/0019-557X.200253, PMID 28218165.

31. Eva Eliza Omar, Islam Md Zakirul, Mosaddek Abu Syed Md, Rahman Md Faizur, Rozario Rini Juliet, Iftekhar AFMd Hassan, et al. Prevalence of stress among medical students: A comparative study between public and private medical schools in Bangladesh. BMC Res Notes. 2015;8:327. doi: 10.1186/ s13104-015-1295-5, PMID 26223786

32. Saeed Abdalla A, Bahnassy Ahmed A, Al-Hamdan Nasser A, Almudhaibery Faisal S, Alyahya Anisah Z. Perceived stress and associated factors among medical students. J Family Community Med. 2016;23(3):166-71. doi: 10.4103/2230-8229.189132, PMID 27625584.

33. Teh CK, Ngo CW, Zulkifli RAb, Vellasamy R, Suresh K. Depression, anxiety and stress among undergraduate students: A cross sectional study. OJEpi. 2015;05(4):260-8. doi: 10.4236/ojepi.2015.54030.

34. Abdel Rahman AG, Al Hashim BN, Al Hiji NK, Al-Abbad Z. Stress among medical Saudi students at College of Medicine, King Faisal University. J Prev Med Hyg. 2013;54(4):195-9. PMID 24779279.

35. Reddy KJ, Menon KR, Thattil A. Academic stress and its sources among university students. Biomedical and Pharmacology Journal. 2018 Mar 25;11(1):531-7.

36. Abdulghani Hamza M, AlKanhal Abdulaziz A, Mahmoud Ebrahim S, Ponnamperuma Gominda G, Alfaris Eiad A. Stress and its effects on medical students: A cross-sectional study at a College of Medicine in Saudi Arabia. J Health Popul Nutr. 2011 Oct;29(5):516-22. doi: 10.3329/jhpn.v29i5.8906, PMID 22106758.

37. Koochaki GM, Charkazi A, Hasanzadeh A, Saedani M, Qorbani M, Marjani A. Prevalence of stress among Iranian medical students: A questionnaire survey. East Mediterr Health J. 2011;17(7):593-8. doi: 10.26719/2011.17.7.593, PMID 21972483.

38. Oku A, Oku O, Owoaje E, Ikpeme B. Prevalence of stress, stressors and coping strategies among medical students in a Nigerian medical school. Afr J Med Health Sci. 2015 Jan 1;14(1):29. doi: 10.4103/2384-5589.153384.

Cite this article: Asdaq SMB, Alamri A, Alhomrani M, Alsanie WF, Sreeharsha N. Perceived Stress and its Triggers among Pharmacy University Students in Comparison to Student of Other Faculties: A Cross Sectional Study. Indian $\mathrm{J}$ of Pharmaceutical Education and Research. 2022;56(1s):s98-s104. 